\title{
Procalcitonin: Importance for the diagnosis of bacterial infections ${ }^{1)}$
}

\author{
Mirjam Christ-Crain', Philipp Schuetz', Andreas \\ R. Huber ${ }^{2}$ and Beat Müller,** \\ ${ }^{1}$ Bereich Innere Medizin, Universitätsspital Basel, \\ Switzerland \\ ${ }^{2}$ Center for Laboratory Medicine, Kantonsspital Aarau, \\ Aarau, Switzerland \\ ${ }^{3}$ Bereich Medizin, Kantonsspital Aarau, Aarau, \\ Switzerland
}

\begin{abstract}
In contrast to calcitonin which is primarily synthesized in the thyroid, procalcitonin is a prohormone which is synthesized in many different tissues of infected organs. To diagnose mild, localized, or early infections an assay needs to have a functional assay sensivity of approximately $0.02 \mu \mathrm{g} / \mathrm{L}$. We demonstrated that procalcitonin modifies the outcome of respiratory infections with regard to minimizing the use of antibiotics and duration of antibiotic treatment. High concentrations, especially over time, indicate high risk of a severe outcome. In this respect, procalcitonin is superior to other infection markers, such as C-reactive protein. High procalcitonin levels can also be found in non-bacterial diseases, such as malaria, severe trauma, burns, and medullar carcinoma of the thyroid. Procalcitonin, as a marker, has improved the diagnosis of bacterial infections. However, procalcitonin needs to be used in conjunction with other laboratory markers, clinical examination, and medical history.
\end{abstract}

Keywords: procalcitonin; infection; pneumonia; antibiotics.

\footnotetext{
1)Original German online version at: http://www.referenceglobal.com/doi/pdf/10.1515/JLM.2008.063.

The German article was translated by Compuscript Ltd. and authorized by the authors.

${ }^{\star}$ Correspondence: Prof. Dr. med. Beat Müller, Klinik für Innere

Medizin, Kantonsspital Aarau AG, Tellstraße, 5001 Aarau,

Switzerland

Tel.: +4162 8386818

Fax: +41628386945

E-mail: happy.mueller@unibas.ch
}

\section{What is procalcitonin?}

Procalcitonin is the pro-hormone of calcitonin [1]. The mature calcitonin hormone is only produced in thyroid $\mathrm{C}$ cells and the relatively few neuroendocrine $\mathrm{K}$ cells of the lung [2]. In the past, calcitonin was believed to control calcium balance and regulate bone metabolism [2], but is known today that neither complete thyroidectomy with removal of all $\mathrm{C}$ cells nor a medullar thyroid carcinoma with $\mathrm{C}$ cell overproduction result in relevant changes of calcium concentrations or bone density. This suggests that mature calcitonin does not (no longer) have an essential physiological function in humans $[3,4]$.

Procalcitonin, on the other hand, seems to play a more important role. In healthy humans, synthesis of procalcitonin is suppressed. Experimental studies have shown, that bacterial toxins and inflammatory mediators stimulate an ectopic, ubiquitous expression of calcitonigen, followed by procalcitonin secretion $[5,6]$. In contrast to the localized production of calcitonin, procalcitonin, when stimulated by a bacterial infection, is mainly produced in parenchymatic organs and differentiated body cells. Figure 1 shows a schematic comparison between regulated secretion (in case of mature calcitonin following endocrine stimulation) and constitutive (non-regulated) secretion (in case of procalcitonin following stimulation by bacterial endotoxins). During this process, blood concentrations of procalcitonin can multiply several 100,000 times [7]. The procalcitonin increase during an infection can be induced directly by microbial toxins (e.g., endotoxins), or indirectly by humoral or cell induced defense reactions (e.g., interleukin-1 $\beta$, interleukin-6, or tumornecrosis-factor- $\alpha$ ). Production can be attenuated by cytokins, which are, e.g., produced in viral infections (such as interferon $\gamma$ ) [6].

Leucocytes produce procalcitonin only in small amounts and temporarily while differentiating from monocytes into macrophages [8]. This explains why procalcitonin blood concentrations found in sepsis patients remain unchanged and high following chemotherapy and complete eradication of leukocytes. White blood cells are therefore not the main source of procalcitonin production. In fact, parenchymatic cells (e.g., liver, fat tissue, and muscle), the larges tissue mass, are the main source of procalcitonin production in sepsis. 


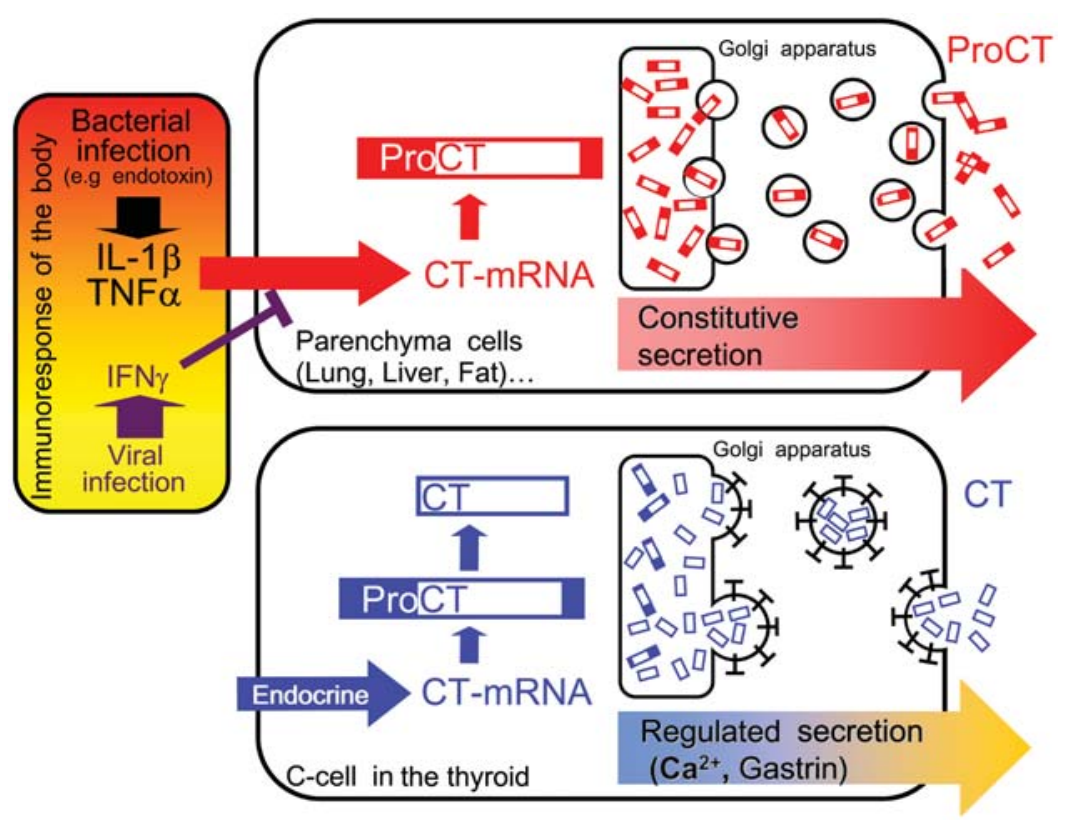

Figure 1 Schematic of procalcitonin production (constitutive versus regulated procalcitonin secretion).

\section{Procalcitonin measurements}

Diagnostic accuracy of procalcitonin and optimal cut-off ranges are largely determined by the sensitivity of the assay. Figure 2 lists cut-off ranges for procalcitonin, and the likelihood, with which a respiratory infection has a bacterial etiology. A summary of assays used and their respective sensitivities is also provided. These cut-offs have to be adjusted to the treatment situation (family physician's office, emergency room, intensive care unit). Ideally, an ultrasensitive assay capable of reliably detecting values in healthy individuals should be used. Such

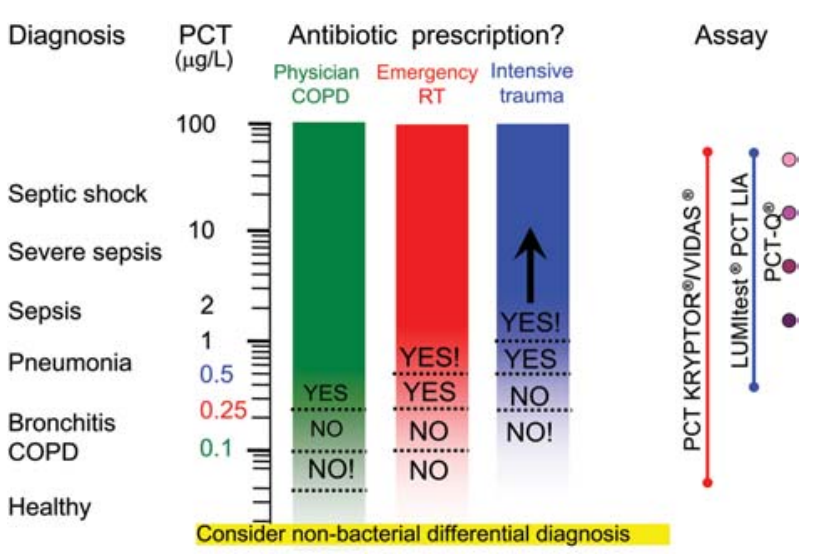

Figure 2 Sensitivity of different procalcitonin assays and cutoff ranges for diagnosis of bacterial infection and indication of antibiotic treatment prior to situation demanding treatment (outpatient treatment to intensive care). RT=respiratory infection, $\mathrm{PCT}=$ procalcitonin, $\mathrm{COPD}=$ chronic obstructive pulmonary disease. manual assays have been available temporarily, and showed promising results $[1,9,10]$. Incomprehensibly, these assays were not developed further, or they were blocked due to patent protection issues. The Kryptor $^{\circledR}$ PCT Assay (Brahms, Hennigsdorf, Germany), which is less sensitive, was evaluated in a number of intervention studies [11-15]. This assay is commercially available, automated, and has a functional assay sensitivity of $0.06 \mu \mathrm{g} / \mathrm{L}$, which is $3-5$ times higher than that of healthy individuals [9]. The assay duration is $19 \mathrm{~min}$, with results being available within one hour in routine clinical settings. The volume of plasma needed is only $20-50 \mu \mathrm{L}$ [16]. A comparable assay is available from other manufacturers (e.g., VIDAS ${ }^{\circledR}$, bioMérieux, Marcy l'étoile, France). The first commercially available assay was the LUMltest $^{\circledR}$ PCT (Brahms, Hennigsdorf, Germany), which was marketed in the 1990s, predominantly in intensive care units. With a functional sensitivity of $\sim 0.3$ bis $0.5 \mu \mathrm{g} / \mathrm{L}$ this assay can, however, only measure strongly elevated procalcitonin concentrations. Its use is therefore restricted to the diagnosis of sepsis in the setting of an intensive care unit. The manual assay is, however, not suitable for $24 \mathrm{~h}$ emergency operations. For less strongly elevated concentrations, which are often encountered in emergency room settings and in the outpatient setting, as well as in beginning and localized infections, the sensitivity of this assay is, however, insufficient. This has resulted in confusing data in the literature. The advantage of a colorimetric "bedside" test $\left(\mathrm{PCT}^{\circledR}-\mathrm{Q}\right.$, Brahms, Hennigsdorf, Germany) is that procalcitonin values are obtained within $30 \mathrm{~min}$. Unfortunately though, this assay is only a semiquantitative, and has insufficient sensitivity to be recommended [18]. 


\section{Procalcitonin in sepsis diagnosis}

The diagnostic reliability of procalcitonin was at first propagated in cases of sepsis. In sepsis, procalcitonin blood concentrations increase more than 100,000-fold, and often correlate with the severity of the disease and its mortality $[7,19,20]$. Several studies have shown that procalcitonin has a good diagnostic reliability in sepsis diagnosis, which exceeds other infection markers (e.g., C-reactive protein or leucocyte count) [7, 21-23]. The cut-off range, which was both sensitive and specific for sepsis diagnosis, was determined to be $0.5-1.0 \mu \mathrm{g} / \mathrm{L}[7$, 20]. The diagnostic reliability of a clinical model for sepsis diagnosis, in particular, could be significantly improved by procalcitonin [24].

Results of all studies were recently summarized in two systematic overviews and meta-analyses [25, 26], where a sensitivity of $88 \%(95 \% \mathrm{Cl}, 80 \%-93 \%)$, was listed for procalcitonin, compared to $75 \%(95 \% \mathrm{Cl}, 62 \%-84 \%)$ for C-reactive protein. Specificity for procalcitonin was $81 \%$ (95\% Cl, 67\%-90\%) compared with 67\% (95\% Cl, 56\%-77\%) for C-reactive protein [25]. Two other recent meta-analyses, however, obtained disappointing results regarding the reliability of procalcitonin in diagnosing sepsis or bacteremia [27, 28]. It has to be noted, though, that observational studies and meta-analyses are biased by choice of procalcitonin assay used, clinical situation, focus of infection, and particularly the gold standard, which separates the diagnosis of sepsis versus noninfectious SIRS and is particularly problematical or even non-existing [29]. It is often forgotten that sepsis is not a diagnosis, but a syndrome. When using biomarkers though, optimal performance can only be achieved after the treating physician has determined the origin and kind of infection, based on medical history and examination of the patient. Particular advantages of using the infection marker procalcitonin versus the inflammation marker C-reactive protein, as a diagnostic marker of bacterial infections are its higher specificity, faster kinetics, and the only minimal effects a steroid therapy has on procalcitonin levels.

Furthermore, differentiation of pneumonia from different forms of differential diagnoses that are accompanied by infiltration in the X-ray image, can be difficult. It was shown that in these cases, the diagnostic reliability of procalcitonin exceeded that of clinical parameters (e.g., body temperature) and C-reactive protein or leukocyte count by far. Again, a significant improvement of the clinical model by procalcitonin could be achieved [23].

Procalcitonin does not seem to be a valuable diagnostic marker in ventilation associated pneumonia (VAP), since an existing VAP could not be predicted in one study by procalcitonin concentrations (J. Chastre, personal information). VAP is an infection with relatively low-virulent pathogens (e.g., P. aeruginosa), which results in relatively mild infections causing low signals. It is, however, a life-threatening inflammation, due to its "Background
Noise", the severity of SIRS and its comorbidity. Consequently, the signal-to-noise-ratio for procalcitonin is unfavorable for the diagnosis of VAP.

\section{Procalcitonin and antibiotic guidance in respiratory infections}

Respiratory infections are the most common reasons for sepsis in humans [7]. $75 \%$ of all antibiotics worldwide are prescribed for respiratory infections, even though most of them are of viral origin. Unnecessary antibiotic therapies are the main reason for increasing antibiotic resistances. A reduction of unnecessary antibiotic therapies would result in cost savings, less side effects, and less resistances to antibiotics. In order to restrict antibiotic therapies, fast and accurate differentiation between clinically relevant bacterial and self-limiting viral infections is crucial. A clinical examination and/or measurement of inflammation parameters, such as C-reactive protein or leukocyte count are usually of little benefit, since lung inflammation can be a result of a bacterial or viral respiratory infection, the symptoms of which often overlap strongly. Due to its superior diagnostic value in the diagnosis of bacterial infections, procalcitonin guided antibiotic therapy is a major progress.

In the ProResp study, we could show that procalcitonin, when measured using the highly sensitive Kryptor assay, can identify bacterial respiratory infections, which require antibiotic treatment [11]. Depending on the procalcitonin concentration, either a variable antibiotic treatment or none at all was recommended (Figure 3) [14]. Procalcitonin guided antibiotic therapy resulted in a significant reduction of antibiotic prescriptions by $50 \%$. The most considerable reduction of antibiotic prescriptions was observed in patients suffering from acute bronchitis and from acute exacerbation of a chronic bronchitis. High procalcitonin concentrations were observed in most pneumonia patients. This supports the theory that the majority of pneumonia cases is of bacterial etiology. Therefore, antibiotic therapy should be the initial treatment of choice in most cases of pneumonia. The recommended duration of such an antibiotic therapy is, however, largely unclear. Depending on the pathogen, 7-21 days of antibiotic therapy are recommended in guidelines, but the optimal duration of therapy was never studied extensively [30]. Many guidelines recommend an adjustment of antibiotic treatment duration to the spectrum of pathogens. In most cases (70\%!) the pathogen remains, however, unknown, even after use of invasive diagnostic procedures Using the biomarker in the ProCAP study, antibiotic treatment duration of severe cases with septic pneumonia requiring hospitalization could be reduced to $<6$ days in the procalcitonin guided group, compared to 13 days in the control group [31].

The ProCOLD study reported that procalcitonin guided antibiotic treatment is also suitable for patients suffering 
Antibiotic therapy based on procalcitonin

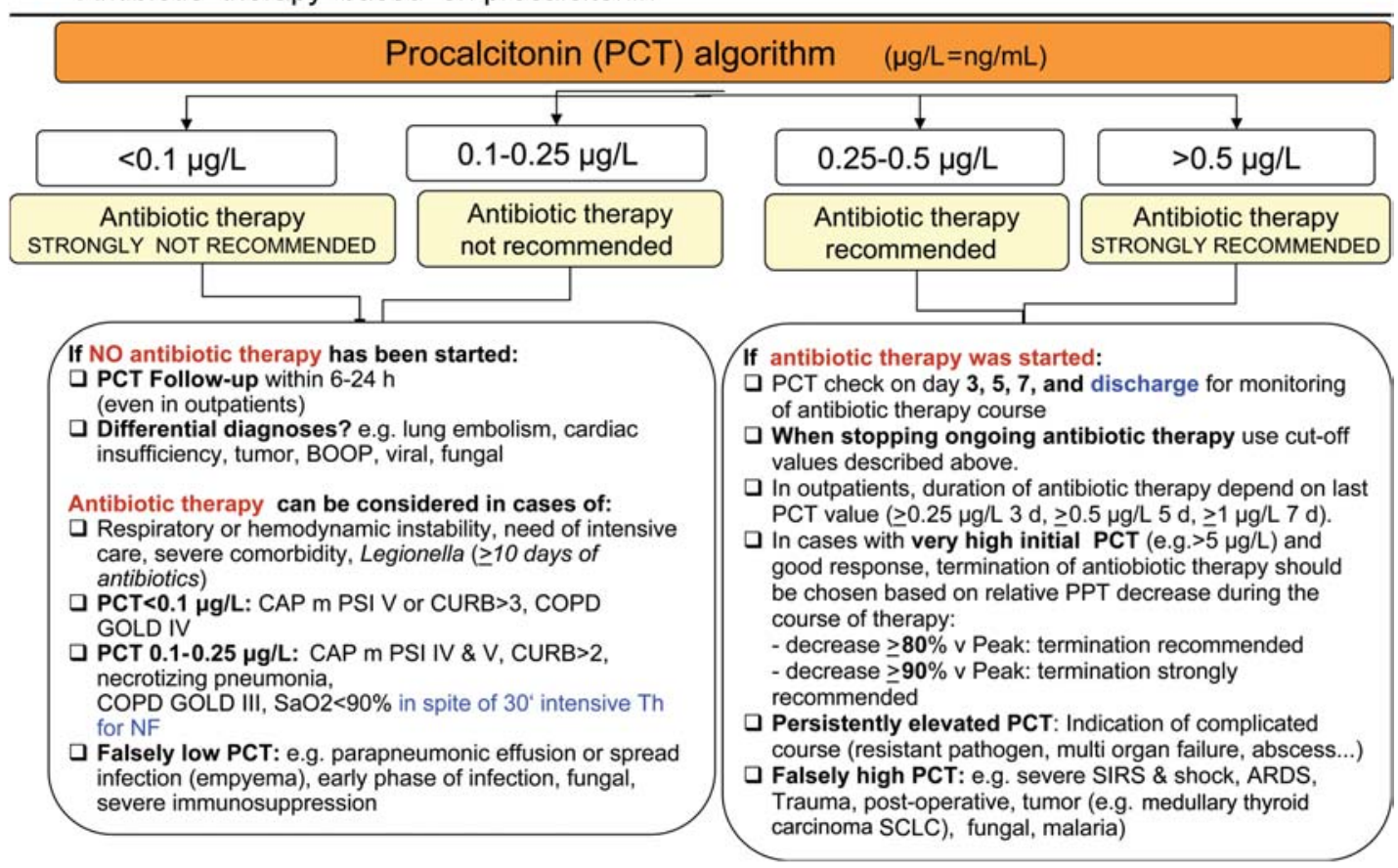

Figure 3 Algorithm for procalcitonin guided antibiotic therapy. Procalcitonin concentrations determine if and to which degree antibiotic therapy is either advised against strongly or less strongly (procalcitonin $<0.1 \mathrm{ug} / \mathrm{L}$ or $<0.25 \mu \mathrm{g} / \mathrm{L}$, respectively), or if it is preferred or strongly recommended (procalcitonin $>0.25 \mu \mathrm{g} / \mathrm{L}$ or $>0.5 \mu \mathrm{g} / \mathrm{L}$, respectively). For severely ill patients, antibiotic therapy may be considered according to pre-defined criteria, even if procalcitonin levels are initially low. During the course of antibiotic therapy, repeated procalcitonin measurements are needed in order to stop treatment using the same cut-off values.

$\mathrm{PCT}=$ Procalcitonin; $\mathrm{COPD}=$ Chronic obstructive pulmonary disease; $\mathrm{PSI}=$ Pneumonia Severity Index; CURB65=Confusion, Urea, Respiration rate, Blood pressure, Age > 65; $\mathrm{BOOP}=$ Bronchiolitis Obliterans Organizing Pneumonia, SCLC =Small Cell Lung Cancer; $\mathrm{SIRS}=$ Systemic Inflammatory Response Syndrome, ARDS = Acute Respiratory Distress Syndrome.

from decreased lung reserve, i.e., patients with acute exacerbation of chronic bronchitis. For these multimorbid patients with impaired lung function, medium-term and long-term outcomes are most important. These outcomes were not affected by the reduction of antibiotics given, as demonstrated by the same relapse rate in both groups within a six-month period [15].

Antibiotic prescriptions for respiratory infections are still predominantly prescribed in family physician practices. In another study conducted in this setting, which included patients with upper and lower respiratory infections, procalcitonin guided antibiotic use was reduced by $75 \%[13,32]$. This was the first "non-inferiority" study, which did not investigate antibiotic use, but patient safety as a primary outcome.

Our concept was confirmed in a pilot "PROSEP" study for infections in intensive care units by a group from Geneva [33], which reduced the average antibiotic treatment duration from 10 to 6 days. As an incidental finding, patients could also be dismissed from the intensive care unit one day early, which is of socioeconomic interest.

These different studies, including their results, are summarized in Figure 4. A multicenter study investigating procalcitonin guided antibiotic therapy and its duration is currently being conducted with more than 1350 patients in various Swiss hospitals [14]. This study also evaluates important prognostic factors, and other biomarkers.

\section{Procalcitonin as diagnostic marker in other infections}

Conventional laboratory diagnostic infection markers and clinical examinations are of limited help in determining bacterial etiology, not only in respiratory infections, but also in infections of other organ systems. Even though positive blood cultures of a typical pathogen are very specific, their sensitivity is low, and results are often obtained as late as two to three days later.

In several other infections, better diagnostic reliability has already been shown for procalcitonin. Procalcitonin is e.g., a more accurate infection marker in the differentiation of viral and bacterial meningitis in children as well as adults [34, 35]. Other markers such as glucose, proteins, cell count in liquor as well as $C$ reactive protein showed more overlap and were less reliable. In a nonrandomized pilot study, procalcitonin guided antibiotic therapy was successful [36].

It was shown during diagnosis of a pancreatitis that procalcitonin concentrations were relatively low in 


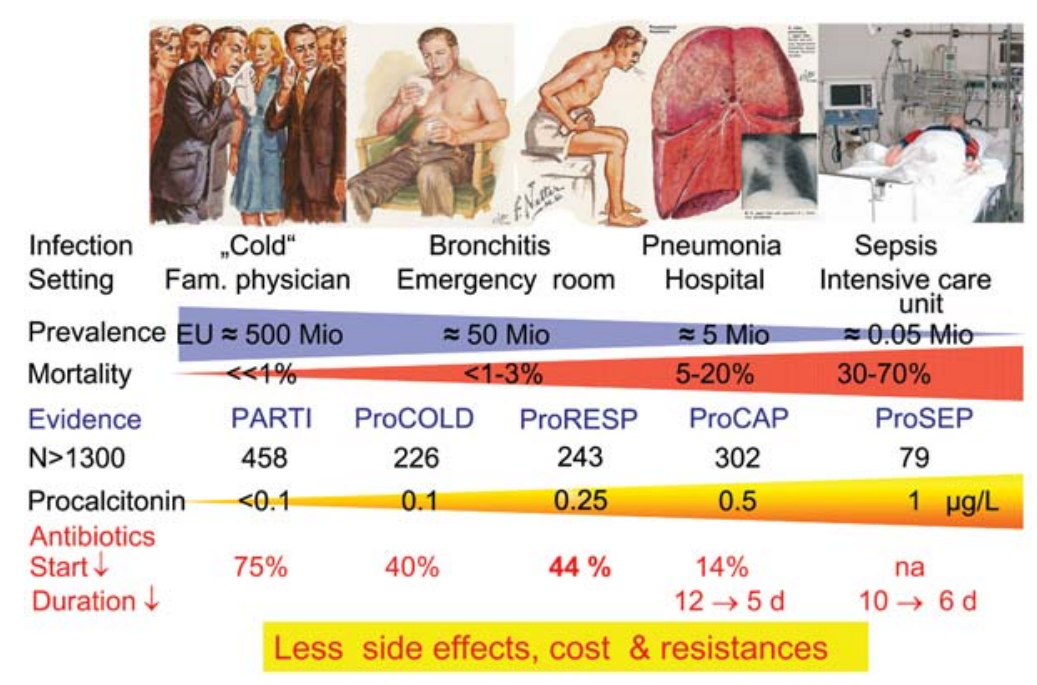

Figure 4 Summary of five published randomized intervention studies on procalcitonin guided antibiotic therapy in respiratory infections and sepsis.

Diagnosis, name, setting, number of patients, and extent of antibiotic reduction as main result are listed for each study.

patients with edematous or toxic pancreatitis, and high in patients with infectious pancreatitis [37]. This could be particularly helpful when monitoring patients requiring surgical intervention due to secondary infection of the initial focus of infection. More conclusive studies are needed to answer this question.

In pyelonephritis, procalcitonin is a helpful marker of the severity of this disease [38]. This was mostly studied in children, where procalcitonin concentrations correlated with the severity of pyelonephritis, particularly with renal scarring [39], contrary to C-reactive protein, interleukin6 , and other markers.

Diagnosis of endocarditis may be clinically challenging as well, particularly due to the variability of its presentation. Echocardiography could, e.g., detect only 43 out of 500 patients suffering from infectious endocarditis [40]. In one of the studies procalcitonin was the only significant independent predictor of infectious endocarditis, which was contrary to other infection markers. The diagnostic reliability of procalcitonin in this study was comparable to that of natriuretic peptide type $B$ in the diagnosis of cardiac insufficiency [41]. Caution is, however, indicated in cases of subacute endocarditis "lenta" where procalcitonin concentrations are often only slightly elevated.

There are also indications that procalcitonin allows better differentiation between bacterial arthritis and gout or rheumatoid arthritis [42]. A new observation study demonstrated a very high diagnostic reliability of procalcitonin in the differential diagnosis of bacterial arthritis versus arthritis of non-bacterial etiology [43]. A cut-off of $0.1 \mu \mathrm{g} / \mathrm{L}$ was associated with maximum diagnostic reliability. Therefore, a highly sensitive assay for the analysis of procalcitonin is required here as well. To date, the diagnostic value of procalcitonin in osteomyelitis has only been investigated in one study. In this study, procalcito- nin concentrations were elevated in only a little more than half of the patients, but values were obtained using a semiquantitative assay [44]. The representative character of these study results is therefore questionable, particularly since only moderately elevated procalcitonin concentrations are expected in osteomyelitis, and similar studies will have to be conducted using a more sensitive assay.

One study reviewed the benefit of procalcitonin in the differentiation of patients with fever and infectious growth of typical skin pathogens (coagulase negative staphylococci) from simple blood contamination [10]. Procalcitonin, when the measurement was repeated using a highly sensitive assay, allowed the differentiation of patients with true sepsis from those where contamination of the cultures had occurred. Interestingly, procalcitonin concentrations in septic patients were elevated even before the clinical manifestation of fever, which is likely caused by colonization of the vein catheter with virulent pathogens, which will subsequently lead to clinical manifestation.

Data collected in gynecology and obstetrics measured procalcitonin associated with rupture of the membranes. Procalcitonin was elevated in the mother's blood after premature rupture of the membranes, compared with women in the same gestational week whose membranes had not ruptured prematurely. A large overlap was, however, noted [45]. The etiology of premature membrane rupture differs, however, widely, and it is not always of infectious nature, which possibly accounts for the large data variability. Both procalcitonin and C-reactive protein were poor predictors of congenital infection or chorionamnionitis [45]. But the relevance of this study is limited, due to the usage of an insensitive test.

Interestingly, procalcitonin is present in breast milk. This seems to be the only place where procalcitonin is 
produced in healthy women without being triggered by an infection. Postpartum levels are further elevated, with a maximum on day 2, and drop subsequently. Any conclusion regarding the underlying biological reason is speculative at current time. Procalcitonin, which has antiinflammatory properties, could play a role in the activation of the immunosystem of the newborn [46]. In one patient who developed mastitis, concentrations dropped initially, and increased again on the sixth day postpartum [46]. High levels of procalcitonin are physiologically found in newborns, possibly due to the bacterial colonization of the newborns' intestines, which are sterile right after birth. Since levels are even more enhanced in newborn sepsis, procalcitonin remains a helpful marker in the diagnosis of newborn sepsis, once cut-off values are adjusted accordingly [47, 48].

A recent study investigated if differentiation between an infected and non-infected diabetic foot could be facilitated by procalcitonin or C-reactive protein. The highest diagnostic reliability in this study was found for a combination of procalcitonin and C-reactive protein. The golden standard used was, however, the clinical determination of infection, which is problematic in this and all other observation studies [49].

For other infections, such as simple urinary tract infections, diverticulitis, adnexits, appendicitis, and a number of others, no data are available at this time regarding the diagnostic relevance of procalcitonin.

\section{Procalcitonin as prognostic marker in other infections}

The prognosis of pneumonia patients is of special importance, since it determines where and how intensively the patient will have to be treated. The severity of pneumonia is commonly classified into five classes according to the pneumonia severity index (PSI), with mortality gradually increasing from class I with $<1 \%$ to class $V$ with up to $30 \%$ [50]. The prognostic relevance of procalcitonin is superior to that of other markers like C-reactive protein or leukocyte count. Neither C-reactive protein and leukocyte count can differentiate between a class I and a class $\mathrm{V}$ pneumonia. Even though procalcitonin concentrations measured at the onset of the disease increase with higher pneumonia severity scores, we found that these values overlap significantly [23]. Prognosis was good for patients with initial PCT values below $0.1-0.25 \mu \mathrm{g} / \mathrm{L}$. More significant information is obtained from the course of procalcitonin. Prognosis is poor for increasing values or the absence of a decline, while rapidly decreasing values indicate a favorable prognosis [24, 51]. The course of procalcitonin is prognostically also relevant in the case of VAP, which contradicts its abovementioned restricted diagnostic reliability. For a procalcitonin concentration of $>0.5 \mu \mathrm{g} / \mathrm{L}$ on day $7 \mathrm{a}$ poor outcome could be detected with a sensitivity of $90 \%$ and a specificity of $88 \%$ [52].
In patients with COPD exacerbations, a procalcitonin concentration $>0.25 \mu \mathrm{g} / \mathrm{mL}$ was predictive of longer hospitalization and transfer to an intensive care unit, it had, however, no prognostic value regarding timing of further exacerbations and long-term outcome [53].

\section{Precautions for the use of procalcitonin}

Results for procalcitonin, like those for all diagnostic markers, of course can be falsely positive or negative [54].

Table 1 lists the main reasons for falsely high or low procalcitonin concentrations. Falsely high procalcitonin concentrations can, e.g., occur in (pro)-calcitonin producing tumors, such as medullary thyroid carcinoma or small cell lung carcinoma, in malaria, in newborns immediately postpartum, or temporarily following surgeries, inflammations, trauma, or burns. It has also been speculated that procalcitonin concentrations in these latter situations are not "falsely" high, but indicative of a true bacterial infection, caused by the omnipresent and virulent intestinal flora, which is translocated through the intestinal wall due to the lack of intestinal perfusion, thereby providing an early sign of a developing bacterial complication $[55,56]$. The course of procalcitonin concentrations remains particularly significant for postoperatively high levels. During an uneventful postoperative course, procalcitonin concentrations drop rapidly from the second to the third postoperative day. Persistently high values indicate an infection [57]. As mentioned above, the diagnosis of sepsis in newborns requires the adjustment of the cut-off ranges.

\section{Table 1 Caveats of procalcitonin.}

Reasons for "falsely" high PCT concentrations (high values in the absence of apparent bacterial infection):

- Physiological in newborns during initial phase

- ARDS (acute respiratory distress syndrome)

- Malaria

- Systemic fungal infections (very variable data)

- Severe trauma

- Following major surgeries [57]

- Severe burns or heat stroke

- Pneumonitis

- Calcitonin producing tumors (such as medular thyroid carcinoma, carcinoid, small cell carcinoma of the lung with paraneoplastic hormone production)

- "Cytokine" storm, e.g., following administration of monoclonal or polyclonal antithymocyte globulin in the treatment of rejection reactions or associated with familiar Mediterranean fever [6, 8].

Reasons for "falsely" low PCT concentrations using an insensitive assay (low concentrations in the presence of bacterial infection):

- Very early during the course of an infection [11].

- Strongly localized infection (e.g., abscess)

- Subacute endocarditis 
Main reasons for falsely low procalcitonin concentrations are strongly localized infections, such as abscess or lung empyema, presumably due to the small amount of infected tissue mass. Furthermore, procalcitonin concentrations can be low during the early phase of an infection $(<6 \mathrm{~h})$. In case of a clinically suspected bacterial infection with low procalcitonin concentrations, the assay should be repeated within $6-24 \mathrm{~h}$, so that a possible delayed increase is not missed.

In summary, it is absolutely essential that procalcitonin levels are always interpreted within the clinical context, based on a detailed medical history and prior clinical examination.

\section{References}

1. Becker KL, Nylen ES, White JC, Müller B, Snider RH Jr. Clinical review 167: Procalcitonin and the calcitonin gene family of peptides in inflammation, infection, and sepsis: a journey from calcitonin back to its precursors. J Clin Endocrinol Metab 2004;1512-25.

2. Becker KL, Müller B, Nylen ES, Cohen R, Silvia OL, Snider $\mathrm{RH}$. Calcitonin gene family of peptides. In: Becker KL, editor. Principles and Practice of Endocrinology and Metabolism. Philadelphia (USA): J.B. Lippincott Co 2001;520-31.

3. Hirsch PF, Lester GE, Talmage RV. Calcitonin, an enigmatic hormone: does it have a function? J Musculoskelet Neuronal interact 2001;1:299-305.

4. Habener JF, Schiller AL. Pathogenesis of renal osteodystrophy - a role for calcitonin? N Engl J Med 1977;296:1112-4.

5. Müller B, White JC, Nylen ES, Snider RH, Becker KL, Habener JF. Ubiquitous expression of the calcitonin-i gene in multiple tissues in response to sepsis. J Clin Endocrinol Metab 2001;86:396-404.

6. Linscheid P, Seboek D, Nylen ES, Langer I, Schlatter M, Becker KL, et al. In vitro and in vivo calcitonin I gene expression in parenchymal cells: a novel product of human adipose tissue. Endocrinology 2003;144:5578-84.

7. Müller B, Becker KL, Schachinger H, Rickenbacher PR, Huber PR, Zimmerli W, et al. Calcitonin precursors are reliable markers of sepsis in a medical intensive care unit. Crit Care Med 2000;28:977-83.

8. Linscheid P, Seboek D, Schaer DJ, Zulewski H, Keller U, Müller B. Expression and secretion of procalcitonin and calcitonin gene-related peptide by adherent monocytes and by macrophage-activated adipocytes. Crit Care Med 2004; 32:1715-21.

9. Snider RH Jr, Nylen ES, Becker KL. Procalcitonin and its component peptides in systemic inflammation: immunochemical characterization. J Investig Med 1997;45:552-60.

10. Schütz P, Müller B, Trampuz A. Serum procalcitonin for discrimination of bood contamination from bloodstream infection due to coagulase-negative staphylococci. Infection 2007;35:352-5.

11. Christ-Crain M, Jaccard-Stolz D, Bingisser R, Gencay MM, Huber PR, Tamm M, et al. Effect of procalcitonin-guided treatment on antibiotic use and outcome in lower respiratory tract infections: cluster-randomised, single-blinded intervention trial. Lancet 2004;363:600-7.

12. Christ-Crain M, Stolz D, Bingisser R, Müller C, Miedinger D, Huber PR, et al. Procalcitonin guidance of antibiotic therapy in community-acquired pneumonia: a randomized trial. Am J Respir Crit Care Med 2006;174:84-93.

13. Briel M, Christ-Crain M, Young J, Schuetz P, Huber P, Periat $\mathrm{P}$, et al. Procalcitonin-guided antibiotic use versus a standard approach for acute respiratory tract infections in primary care: study protocol for a randomised controlled trial and baseline characteristics of participating general practitioners [ISRCTN73182671]. BMC Fam Pract 2005;6:34.

14. Schuetz P, Christ-Crain M, Wolbers M, Schild U, Thomann $\mathrm{R}$, Falconnier $\mathrm{C}$, et al. Procalcitonin guided antibiotic therapy and hospitalization in patients with lower respiratory tract infections: a prospective, multicenter, randomized controlled trial. BMC Health Serv Res 2007;7:102.

15. Stolz D, Christ-Crain M, Bingisser R, Leuppi J, Miedinger D, Müller $\mathrm{C}$, et al. Antibiotic treatment of exacerbations of COPD: a randomized, controlled trial comparing procalcitonin-guidance with standard therapy. Chest 2007;131:919.

16. Meisner M. Pathobiochemistry and clinical use of procalcitonin. Clin Chim Acta 2002;323:17-29.

17. Whang KT, Steinwald PM, White JC, Nylen ES, Snider RH, Simon GL, et al. Serum calcitonin precursors in sepsis and systemic inflammation. J Clin Endocrinol Metab 1998;83: 3296-301.

18. Meisner M, Brunkhorst FM, Reith HB, Schmidt J, Lestin HG, Reinhart K. Clinical experiences with a new semi-quantitative solid phase immunoassay for rapid measurement of procalcitonin. Clin Chem Lab Med 2000;38:989-95.

19. Assicot M, Gendrel D, Carsin H, Raymond J, Guilbaud J, Bohuon C. High serum procalcitonin concentrations in patients with sepsis and infection. Lancet 1993;341:515-8.

20. Al-Nawas B, Krammer I, Shah PM. Procalcitonin in diagnosis of severe infections. Eur J Med Res 1996;1:331-3.

21. de Werra I, Jaccard C, Corradin SB, Chiolero R, Yersin B, Gallati $\mathrm{H}$, et al. Cytokines, nitrite/nitrate, soluble tumor necrosis factor receptors, and procalcitonin concentrations: comparisons in patients with septic shock, cardiogenic shock, and bacterial pneumonia. Crit Care Med 1997;25: 607-13.

22. Gendrel D, Bohuon C. Procalcitonin as a marker of bacterial infection. Pediatr Infect Dis J 2000;19:679-87.

23. Müller B, Harbarth S, Stolz D, Bingisser R, Mueller C, Leuppi $\mathrm{J}$, et al. Diagnostic and prognostic accuracy of clinical and laboratory parameters in community-acquired pneumonia. BMC Infect Dis 20072;7:10.

24. Harbarth S, Holeckova K, Froidevaux C, Pittet D, Ricou B, Grau GE, et al. Diagnostic value of procalcitonin, interleukin6 , and interleukin-8 in critically ill patients admitted with suspected sepsis. Am J Respir Crit Care Med 2001;164: 396-402.

25. Simon L, Gauvin F, Amre DK, Saint-Louis P, Lacroix J. Serum procalcitonin and C-reactive protein levels as markers of bacterial infection: a systematic review and metaanalysis. Clin Infect Dis 2004;39:206-17.

26. Uzzan B, Cohen R, Nicolas P, Cucherat M, Perret GY. Procalcitonin as a diagnostic test for sepsis in critically ill adults and after surgery or trauma: a systematic review and metaanalysis. Crit Care Med 2006;34:1996-2003.

27. Tang BM, Eslick GD, Craig JC, McLean AS. Accuracy of procalcitonin for sepsis diagnosis in critically ill patients: systematic review and meta-analysis. Lancet Infect Dis 2007;7:210-7.

28. Jones AE, Fiechtl JF, Brown MD, Ballew JJ, Kline JA. Procalcitonin test in the diagnosis of bacteremia: a meta-analysis. Ann Emerg Med 2007;50:34-41. 
29. Müller B, Christ-Crain M, Schuetz P. Meta-analysis of procalcitonin for sepsis detection. Lancet Infect Dis 2007; 7:498-9; author reply 502-3.

30. File TM Jr, Mandell LA. What is optimal antimicrobial therapy for bacteremic pneumococcal pneumonia? Clin Infect Dis 2003;36:396-8.

31. Christ-Crain M, Stolz D, Bingisser R, Huber P, Leuppi J, Müller $\mathrm{C}$, et al. Procalcitonin guidance significantly reduces antibiotic duration in community-acquired pneumonia. 45th Conference on Antimicrobial Agents and Chemotherapy (ICAAC) Washington DC. 2005.

32. Briel M, Schuetz P, Mueller B, Young J, Schild U, Nusbaumer $\mathrm{C}$, Periat $\mathrm{P}$, et al. Procalcitonin-guided antibiotic use vs. a standard approach for acute respiratory infections in primary care. Arch Int Med 2008\# press.

33. Nobre V, Harbarth S, Graf JD, Rohner P, Pugin J. Use of procalcitonin to shorten antibiotic treatment duration in septic patients: a randomized trial. Am J Respir Crit Care Med 2008;177:498-505.

34. Gendrel D, Raymond J, Assicot M, Moulin F, Iniguez JL, Lebon $\mathrm{P}$, et al. Measurement of procalcitonin levels in children with bacterial or viral meningitis. Clin Infect Dis 1997; 24:1240-2.

35. Viallon A, Zeni F, Lambert C, Pozzetto B, Tardy B, Venet C, et al. High sensitivity and specificity of serum procalcitonin levels in adults with bacterial meningitis. Clin Infect Dis 1999;28:1313-6.

36. Marc E, Menager C, Moulin F, Stos B, Chalumeau M, Guerin $S$, et al. [Procalcitonin and viral meningitis: reduction of unnecessary antibiotics by measurement during an outbreak]. Arch Pediatr 2002;9:358-64.

37. Rau B, Steinbach G, Gansauge F, Mayer JM, Grunert A, Beger HG. The potential role of procalcitonin and interleukin 8 in the prediction of infected necrosis in acute pancreatitis. Gut 1997;41:832-40.

38. Tullus K, Fituri O, Linne T, Escobar-Billing R, Wikstad I, Karlsson A, et al. Urine interleukin- 6 and interleukin-8 in children with acute pyelonephritis, in relation to DMSA scintigraphy in the acute phase and at 1-year follow-up. Pediatr Radiol 1994;24:513-5.

39. Benador N, Siegrist CA, Gendrel D, Greder C, Benador D, Assicot M, et al. Procalcitonin is a marker of severity of renal lesions in pyelonephritis. Pediatrics 1998;102:1422-5.

40. Greaves K, Mou D, Patel A, Celermajer DS. Clinical criteria and the appropriate use of transthoracic echocardiography for the exclusion of infective endocarditis. Heart 2003; 89:273-5.

41. Mueller C, Buser P. B-type natriuretic peptide (BNP): can it improve our management of patients with congestive heart failure? Swiss Med Wkly 2002;132:618-22.

42. Martinot M, Sordet C, Soubrier M, Puechal X, Saraux A, Liote $F$, et al. Diagnostic value of serum and synovial procalcitonin in acute arthritis: a prospective study of 42 patients. Clin Exp Rheumatol 2005;23:303-10.

43. Hügle T, Schuetz P, Mueller B, Laifer G, Tyndall A, Regenass $S$, et al. Serum procalcitonin for discrimination between septic and non-septic arthritis. Clin Exp Rheumatol 2008; 26:453-6.

44. Butbul-Aviel Y, Koren A, Halevy R, Sakran W. Procalcitonin as a diagnostic aid in osteomyelitis and septic arthritis. Pediatr Emerg Care 2005;21:828-32.

45. Torbe A. Maternal plasma procalcitonin concentrations in pregnancy complicated by preterm premature rupture of membranes. Mediators Inflamm 2007;2007:35782.

46. Struck J, de Almeida P, Bergmann A, Morgenthaler NG. High concentrations of procalcitonin but not mature calcitonin in normal human milk. Horm Metab Res 2002;34:460-5.

47. Chiesa C, Panero A, Rossi N, Stegagno M, De Giusti M, Osborn JF, et al. Reliability of procalcitonin concentrations for the diagnosis of sepsis in critically ill neonates. Clin Infect Dis 1998;26:664-72.

48. van Rossum AM, Wulkan RW, Oudesluys-Murphy AM. Procalcitonin as an early marker of infection in neonates and children. Lancet Infect Dis 2004;4:620-30.

49. Jeandrot A, Richard JL, Combescure C, Jourdan N, Finge $\mathrm{S}$, Rodier M, et al. Serum procalcitonin and C-reactive protein concentrations to distinguish mildly infected from noninfected diabetic foot ulcers: a pilot study. Diabetologia 2008;51:347-52.

50. Fine MJ, Auble TE, Yealy DM, Hanusa BH, Weissfeld LA, Singer DE, et al. A prediction rule to identify low-risk patients with community-acquired pneumonia. $\mathrm{N}$ Engl $\mathrm{J}$ Med 1997;336:243-50.

51. Jensen JU, Heslet L, Jensen TH, Espersen K, Steffensen P, Tvede M. Procalcitonin increase in early identification of critically ill patients at high risk of mortality. Crit Care Med 2006;34:2596-602.

52. Luyt CE, Guerin V, Combes A, Trouillet JL, Ayed SB, Bernard $M$, et al. Procalcitonin kinetics as a prognostic marker of ventilator-associated pneumonia. Am J Respir Crit Care Med 2005;171:48-53.

53. Stolz D, Christ-Crain M, Morgenthaler NG, Leuppi J, Miedinger $\mathrm{D}$, Bingisser $\mathrm{R}$, et al. Copeptin, $\mathrm{C}$-reactive protein, and procalcitonin as prognostic biomarkers in acute exacerbation of COPD. Chest 2007;131:1058-67.

54. Christ-Crain M, Müller B. Procalcitonin in bacterial infections - hype, hope, more or less? Swiss Med Wkly 2005;135: 451-60.

55. Molter GP, Soltesz S, Kottke R, Wilhelm W, Biedler A, Silomon M. Procalcitoninplasmakonzentration und systemische inflammatorische Antwort nach verschiedenen operativen Eingriffen. Anaesthesist 2003;52:210-7.

56. Lendemans S, Kreuzfelder E, Waydhas C, Nast-Kolb D, Flohe S. Verlauf und prognostische Bedeutung immunologischer Funktionsparameter nach schwerem Trauma. Der Unfallchirurg 2004;107:203-10.

57. Meisner M, Tschaikowsky K, Hutzler A, Schick C, Schuttler J. Postoperative plasma concentrations of procalcitonin after different types of surgery. Intensive Care Med 1998; 24:680-4. 